\title{
MULTICULTURALISM IN CHILDREN'S LITERATURE: A STUDY OF POETRIES BY ELEMENTARY SCHOOL STUDENTS \\ Anang Sudigdo $^{1 *}$, St. Y. Slamet ${ }^{2}$, Retno Winarni ${ }^{3}$, Nugraheni Ekowardani ${ }^{4}$
}

${ }^{1}$ Doctoral Student of Indonesia Language Education, Universitas Sebelas Maret, Surakarta, Indonesia; ${ }^{2.3,4}$ Faculty of

Teacher Training and Education, Universitas Sebelas Maret, Surakarta, Indonesia.

Email: ${ }^{1 *}$ anang.sudigdo@ustjogja.ac.id, ${ }^{2}$ slametsty@yahoo.com, ${ }^{3}$ retnowinarni@ staff.uns.ac.id,

nugraheniekowardani_99@yahoo.co.id

\author{
Article History: Received on $24^{\text {th }}$ March 2020, Revised on $24^{\text {th }}$ April 2020, Published on $16^{\text {th }}$ May 2020
}

\begin{abstract}
Purpose of the Study: This study aims to explain the collection of children's poetry by elementary school students in a book entitled "Keragaman Budaya Indonesia" and "Sehimpun Puisi. Resep Membuat Jagat Raya" in the multiculturalism perspective.

Methodology: This study used the qualitative study paradigm rules with the content analysis method. The data in this study were the multiculturalism values in children's poetry. The data were sourced from a poetries book by elementary school students. They were then analyzed using interactive analysis techniques (data reduction, data presentation, and verification).
\end{abstract}

Main Findings: The findings showed that there are fourteen indicators of multiculturalism, among others, respect for cultural equality, social class, ethnicity, gender, language, religion, race, skin color, and pluralism, equality of rights, customs, behavior patterns, education equality and tolerance in the poetries book.

Applications of this study: The results of this study can be useful for teachers and elementary school students in Indonesia in teaching poetry writing and inculcating the values of multiculturalism. Also, it can be beneficial for the lecturers and the university students of Elementary School Teacher Education in Indonesia in teaching children's literature with multiculturalism.

Novelty/Originality: The novelty of this research/study is to explore a collection of children's poetry books written by elementary school students from the perspective of multiculturalism. The importance of early recognition of the value of multiculturalism in children is used to teach children to respect each other and live in harmony and free from the prejudices of religious discrimination, gender, race, culture, skin color, social class, educational equality, and student diversity.

Keywords: Children's Literature, Multiculturalism, Children's Poetry, Keragaman Budaya Indonesia, Sehimpun Puisi Resep Membuat Jagat Raya.

\section{INTRODUCTION}

Education is one way to take to foster a spirit of unity behind Indonesia's diversity. Education is also an institution to prepare a new generation in the future. The new generation is expected to be able to live according to the prevailing system, especially to live independently and carry out their role in the future. In detail, the national ideals associated with educational activities have been outlined in the National Education System Law No.20 of 2003 stating that the purpose of national education is to develop the students' potentials to become human beings who believe in and have faith in God Almighty, have good morals, creative, are healthy, capable, knowledgeable, and independent, and become democratic and responsible citizens.

Furthermore, the principle of implementing education has also been clearly described in the National Education System Law, which is stated in article 4, that: 1) Education is carried out in a democratic, fair and non-discriminatory manner by upholding human rights, religious values, cultural values, and national diversity; 2) Education is organized as a systemic unit with an open and multi-meaning system;3) Education is organized as a process of civilization and empowerment of students that lasts throughout life; 4) Education is conducted by giving an example, building a will, and developing the creativity of students in the learning process; 5) Education is organized by developing the cultures of reading, writing, and counting for all citizens; and 6) Education is carried out by empowering all components of society through participation in the administration and quality control of educational services.

The function of national education, as stated in Chapter II article 3, is to develop capabilities and shape the character and civilization of a dignified nation to educate the nation's life. Besides, the function of education can also be seen in two perspectives. First, at the micro (specific) level, education serves to consciously help develop the physical and spiritual development of students. Second, at the macro (general) level, education serves as a personal, citizen, cultural, and nation development.

Education is one of the most effective media to create generations who have a view that diversity must be appreciated constructively (Naim, Ngainun \& Sauqi, 2011). Multicultural education refers to the learning of knowledge, appropriate attitudes, and skills related to respect and appreciation for cultural differences and other differences that include race, 
ethnicity, religion, and others Abdullah (Abdullah, 2009). Multicultural education also includes issues related to socioeconomic status, ethnicity, and gender (Santrock, 2015).

Education is needed to introduce multiculturalism values which include the diversity of religions, ethnicities, languages, cultures, skin color, gender, social class, educational equality, language, and so on. In instilling the values of diversity, multicultural awareness is needed. Multicultural awareness is awareness based on the values of multiculturalism. Multiculturalism is a concept that a community in the national context can recognize diversity, difference, and cultural pluralism, race, tribes, ethnicity, religion, and so on (Mahfud, 2011). Multiculturalism includes discussions about social class, gender, ethnicity, race, religion, and disabled people (Rachmawati, Pai, Yi-Fong \& Chen, 2014). Multiculturalism is significant in realizing peace because it necessitates the absence of majority culture and the tyranny of minority culture dominations. All of them grow together and have the same opportunity to achieve collective prosperity. Each culture has the same opportunity to show its existence without discrimination (Mahfud, 2011).

Multicultural Education gives birth to people who are ready to interact with and respect each other despite their different lives and socioeconomic status from one another (Maliki, 2010). (Miftah, 2016) Multicultural education sees humanity broadly, not only racial aspects but also injustice, poverty, oppression, minority backwardness on various sides (social, cultural, economic, and educational). Multicultural education respects differences and teaches tolerance among people to make a part of social community relations. Multicultural education is a concept made to create equal educational opportunities for all Indonesian citizens. One of the goals of multicultural education is to build the construction of students' knowledge, attitudes, and abilities to contribute to a pluralistic democratic society. The construction of knowledge, attitudes, and abilities is needed by students to interact and communicate in a plural society.

Multiculturalism values need to be introduced to students from an early age because they grow and live in a plural country that is Indonesia. Indonesia is a nation whose society is very pluralistic and pluralist. The diversity that exists in Indonesia is a treasure that should be preserved and provides dynamism for Indonesian people. On the other hand, it can be a starting point of disputes and conflicts (both vertical and horizontal) for Indonesian people (Zakiyuddin, 2015). A nation's pluralism in a horizontal perspective can be seen from differences in religion, ethnicity, regional languages, geography, and culture. Pluralism in a vertical perspective can be seen from differences in levels of education, economy, and socio-culture.

This pluralism phenomenon is like a double-edged knife. One side has a positive impact, a rich cultural diversity. The other side can have a negative impact because if there are no tolerance, mutual respect, and upholding unity in diversity and pluralism, it can trigger conflicts between groups of people which in turn can cause security, social, political, and economic instabilities. (Miftah, 2016) said that discrimination, conflicts, and socio-religious, political, economic, cultural, and educational crises, increasingly widespread in this country.

In facing cultural pluralism, a new paradigm that is more tolerant and elegant is needed to prevent and solve the problem of cultural clashes, namely the multiculturalism paradigm. This is important to direct students in addressing the reality of diverse societies so that they will have an appreciative attitude towards the diversity of these differences. Multiculturalism is essential and urgent to be implemented in the praxis of education in Indonesia because it can serve as an alternative means of conflict resolution (Zakiyuddin, 2015). Multicultural education is a way to teach diversity. Multicultural education teaches inclusivism, pluralism, and mutual respect for all people and cultures.

Instilling multicultural education to students from elementary, secondary to tertiary levels aims to teach students to grow in a world free from prejudice against religious, gender, race, skin color, culture, and social class discriminations, and free from suffering due to rejection and exclusion (Zakiyuddin, 2015). The internalization of the multiculturalism values teaches students to respect one another for the equality of culture, social class, ethnicity, gender, language, religion, race, skin color, pluralism, rights, customs, behavior patterns, education, and tolerance.

\section{LITERATURE REVIEW}

Ratna, (2005) Explained that diversity in Indonesia is the reality of a nation consisting of various tribes, races, religions, customs, and patterns of behaviors and habits. Thus, literary works that reflect such diversities are essentially multicultural literary works. Local color literature as part of multicultural literature plays an important role in introducing cultural treasures (Taufiq, 2017). The development of multicultural perspectives, including through the study of multicultural literature, is one of the forces to shape multicultural attitudes (Taufiq, 2017). Colby \& Lyon, explain that multicultural literature encourages children to identify not only with their own culture but also with others' cultures, thereby promoting the discussion of diversity (McIver, 2018).

Katz said that multicultural literature describes all types of culture, which includes various races, genders, religions, languages, socioeconomic classes, and ethnicities, and which provides opportunities to open children's minds to lifestyles different from theirs (McIver, 2018). Canales, Lucido \& Salas, stated that multicultural literature engages readers about people from diverse cultural, linguistic, and religious groups (McIver, 2018). Canales, Lucido\& Salas also said that multicultural picture books can be used as a tool to engage children and to offer views of diversity in stories that are filled with characters from other ethnic groups (McIver, 2018). Taylor mentions that children's books are a 
powerful learning tool that helps children understand discrimination (McIver, 2018). The books about multicultural literature can be in the form of fact and fiction stories (Steiner, Nash, \& Chase, 2008a).

Based on this fact, the values of multiculturalism should be instilled in students from an early age. The internalization of multiculturalism values can be given through children's literature, one of which is through children's poetry. Children's literature that contains multiculturalism can be in the form of storybooks from various regions, for example, poetry, folklore, fairy tales, and fiction (Mingshui, 2002). (Sarumpaet, 2010) said that children's literature is the literature that can be read by children. (Hasanuddin, 2015) argues that children's literature is a work that is "suitable" to be read, heard, or consumed by children. Children's literature is very close to children's lives and fictional aspects of imagination. (Nurgiyantoro, 2013) said that children's literature is the literature that can be responded to and understood by children emotionally and psychologically. It is generally from concrete facts easy to be imagined. According to (Heru, 2013), children's literature is the literature that, in terms of content and language, is following the level of intellectual and emotional development of children. However, not all literature provides the teachings of multiculturalism. Therefore, it is necessary to recognize the multiculturalism values through children's literature.

(Sudigdo, Slamet, Winarni, \& Ekowardani, 2019) The presence of literature for children has a great psychological impact on children's mental health. The experiences of a child from childhood will affect his life and development. Childhood is a period of growth marked by high curiosity. Children tend to be curious about a lot of good things related to themselves, their families, and the environment around them. They can receive all forms of information that are logical and reasonable or not. This makes children often ask both their parents and teachers at school. High curiosity must be responded with an active attitude to provide information and instill positive values expected to the children. Therefore, children's literature can be an appropriate tool for answering this need.

Some important studies on multiculturalism in poetry have been carried out by (1) (Monanti, Bassil, Lilian, Author, \& Fredrick, 2014) exploring the contribution of children's oral poetry in the formation of acceptable personalities among children and society and as an effort to reduce the number of children with mangled personalities and by (2) (McIver, 2018) exploring the representation and depiction of multicultural families in children's picture books within kindergarten classroom libraries. The results of this study show that children who interact with current picture books predominantly see Korean faces; (3) (Abdullah, 2009) Multicultural education becomes an important component in early childhood education. This article discusses the problems and challenges of preventing early conflicts over social inequalities and respecting one another in early childhood education; (4) (Kijima, 2005) This article reports a case study about the process experienced by Japanese International students (JIs) in a suburban high school. The study examined the relationship between schooling, multiculturalism, and cultural identity. The major findings of the study were that Jis negotiated new cultural identities in the process of facing difficulties of language, cultural understanding and racism as barriers; (5) (Kamil, 2018) exploring tolerance and intolerance of the diversity of the people of Yogyakarta in the midst of cultural, racial and religious modernity. Referring to various studies conducted, the studies on children's literary multiculturalism have been conducted. However, the study that examines elementary school students' poetry containing multiculturalism has not been done.

\section{OBJECTIVES AND HYPOTHESIS}

This study is an interdisciplinary study of children's literature of multiculturalism. The purpose of this research to explore children's poetry books written by elementary school students entitled "Keragaman Budaya Indonesia" and "Sehimpun Puisi. Resep Membuat Jagat Raya" in the multiculturalism perspective. The two poetry books are written by children and are the result of the imagination of elementary school children. The results of the hypotheses of the researcher indicate that the collection of poems represents the work of children with multiculturalism content. The poetry can be used as a means for the introduction of multiculturalism values to students.

\section{METHODOLOGY}

This research is an attempt to explore the content of multiculturalism in the collection of poetry by elementary school students. This research is descriptive qualitative research with a content analysis method. (Klaus, 2004)the content analysis focuses on valid data references of content. This method is used to examine the contents of a document or data source. Sources of research data are poem collection books "Keragaman Budaya Indonesia" and "Sehimpun Puisi. Resep Membuat Jagat Raya" written by elementary school students. The use of the books is based on the results of the hypothesis of the researcher that the two poem collection books represent the works of elementary school students with multiculturalism content. Data sources are explained in the following table.

Table 1: Poetries data

\begin{tabular}{llll}
\hline No & The Book Title & Publication Year & Publisher \\
\hline 1 & Keragaman Budaya Indonesia & 2019 & Pataba Press \\
\hline 2 & Sehimpun Puisi. Resep Membuat Jagat Raya & 2018 & Karabarita \\
\hline
\end{tabular}

In more detail, table 1: data poetries will be described in table 2: data and data sources below. 
Table 2: Data and data sources

\begin{tabular}{|c|c|c|c|c|c|}
\hline No & $\begin{array}{c}\text { The Student's } \\
\text { Name }\end{array}$ & School & $\begin{array}{c}\text { The Poetries } \\
\text { Title }\end{array}$ & $\begin{array}{c}\text { Multiculturalism } \\
\text { Values }\end{array}$ & Source \\
\hline 1 & $\begin{array}{l}\text { Meita Ciben } \\
\text { Rubiyanisa }\end{array}$ & $\begin{array}{c}\text { Sekolah Dasar Negeri } \\
\text { Margomulyo, Yogyakarta }\end{array}$ & $\begin{array}{l}\text { My Cultural } \\
\text { Diversity }\end{array}$ & Cultural diversity & $\frac{\text { (Rubiyanisa, }}{\underline{2019)}}$ \\
\hline 2 & $\begin{array}{l}\text { Abinaya Ghina } \\
\text { Jamela }\end{array}$ & $\begin{array}{c}\text { Sekolah Dasar Negeri } \\
\text { Gondolayu, Yogyakarta }\end{array}$ & Tempeh & $\begin{array}{l}\text { Social class } \\
\text { equality }\end{array}$ & (Jamela, 2018) \\
\hline 3 & Abi & $\begin{array}{c}\text { Sekolah Dasar Negeri Kotagede } \\
\text { 1, Yogyakarta }\end{array}$ & Ethnics & $\begin{array}{l}\text { Respect for ethnic } \\
\text { diversity }\end{array}$ & (Abi, 2019) \\
\hline 4 & $\begin{array}{l}\text { Abinaya Ghina } \\
\text { Jamela }\end{array}$ & $\begin{array}{c}\text { Sekolah Dasar Negeri } \\
\text { Gondolayu, Yogyakarta }\end{array}$ & $\begin{array}{l}\text { The Story of a } \\
\text { Woman }\end{array}$ & Gender equality & (Jamela, 2018) \\
\hline 5 & $\begin{array}{l}\text { Chicanti Putri } \\
\text { Yuniarahma }\end{array}$ & $\begin{array}{c}\text { Sekolah Dasar Negeri } \\
\text { Mendungan } 2 \text { Yogyakarta }\end{array}$ & My Indonesia & $\begin{array}{c}\text { Respect for } \\
\text { language diversity }\end{array}$ & $\frac{\text { (Yuniarahma, }}{\underline{2019)}}$ \\
\hline 6 & FiraS etyawati & $\begin{array}{c}\text { Sekolah Dasar Negeri Kotagede } \\
4 \text { Yogyakarta }\end{array}$ & Religion & $\begin{array}{l}\text { Respect for } \\
\text { religious diversity }\end{array}$ & $\frac{\text { (Setyawati, }}{2019)}$ \\
\hline 7 & Lulu Munakumala & $\begin{array}{c}\text { Sekolah Dasar Negeri } \\
\text { Jomblangan Yogyakarta }\end{array}$ & $\begin{array}{c}\text { Ethnic } \\
\text { Difference }\end{array}$ & $\begin{array}{l}\text { Respect for racial } \\
\text { diversity }\end{array}$ & $\frac{\text { (Munakumala, }}{\underline{2019)}}$ \\
\hline 8 & M. Yuma Briliant & $\begin{array}{c}\text { Sekolah Dasar Islam } \\
\text { Internasional Al Abidin } \\
\text { Surakarta }\end{array}$ & $\begin{array}{l}\text { Black and } \\
\text { White }\end{array}$ & $\begin{array}{l}\text { Respect for skin } \\
\text { color diversity }\end{array}$ & (Briliant, 2019) \\
\hline 9 & Rafi & $\begin{array}{c}\text { Sekolah Dasar Negeri } \\
\text { Jomblangan Yogyakarta }\end{array}$ & $\begin{array}{c}\text { Love and } \\
\text { Respect Each } \\
\text { Other }\end{array}$ & Pluralisms & (Rafi, 2019) \\
\hline 10 & $\begin{array}{l}\text { Abinaya Ghina } \\
\text { Jamela }\end{array}$ & $\begin{array}{c}\text { Sekolah Dasar Negeri } \\
\text { Gondolayu, Yogyakarta }\end{array}$ & Slave & $\begin{array}{c}\text { Espect for } \\
\text { equality of rights }\end{array}$ & (Jamela, 2018) \\
\hline 11 & $\begin{array}{l}\text { Abinaya Ghina } \\
\text { Jamela }\end{array}$ & $\begin{array}{l}\text { Sekolah Dasar Negeri } \\
\text { Gondolayu, Yogyakarta }\end{array}$ & Papua & $\begin{array}{l}\text { Respect for the } \\
\text { diversity of } \\
\text { customs }\end{array}$ & (Jamela, 2018) \\
\hline 12 & $\begin{array}{l}\text { Abinaya Ghina } \\
\text { Jamela }\end{array}$ & $\begin{array}{c}\text { Sekolah Dasar Negeri } \\
\text { Gondolayu, Yogyakarta }\end{array}$ & Hero & $\begin{array}{l}\text { Pattern of } \\
\text { behavior }\end{array}$ & (Jamela, 2018) \\
\hline 13 & $\begin{array}{l}\text { Abinaya Ghina } \\
\text { Jamela }\end{array}$ & $\begin{array}{l}\text { Sekolah Dasar Negeri } \\
\text { Gondolayu, Yogyakarta }\end{array}$ & $\begin{array}{l}\text { The Story of } \\
\text { A Woman }\end{array}$ & $\begin{array}{l}\text { Educational } \\
\text { equality }\end{array}$ & (Jamela, 2018) \\
\hline 14 & Icha Amelia & $\begin{array}{l}\text { Sekolah Dasar Negeri Kotagede } \\
1 \text { Yogyakarta }\end{array}$ & Multicultural & Tolerance & (Amelia, 2019) \\
\hline
\end{tabular}

The research data in the form of words, phrases, diction/word choice, and sentences that contain multiculturalism values. The document analysis stage starts from the document reading and recording to document analysis. The document analysis aims to determine the multiculturalism content in poetry. The data analysis techniques used in this study are interactive analysis techniques including data reduction, data presentation, and conclusion/verification that occur simultaneously (Miles, 2009).

\section{DISCUSSION / ANALYSIS}

Based on the results of the analysis of the collections of poetries "Keragaman Budaya Indonesia" and "Sehimpun Puisi. Resep Membuat Jagat Raya" by elementary school students. At the discussion stage, the fourteen contents of the multiculturalism values in the poetry are elaborated. The fourteen multiculturalism contents include mutual respect for cultural diversity, social class diversity, ethnic diversity, gender diversity, language diversity, religious diversity, racial diversity, skin color diversity, pluralism, equality of rights, diversity of customs, behavior pattern diversity, educational equality, and tolerance. The multiculturalism indicators were obtained based on the opinions of the experts which were then compiled into a multiculturalism indicator construction. A complete description of the multiculturalism values can be seen in the of the excerpts of the poetry as follows.

\section{Respect for Cultural Diversity}

\section{My Cultural Diversity}

Indonesia has a lot of diversity

One of them is cultural diversity

There are many types of culture

One of them is the local dance

Bhedaya dance is the name of a dance in my place 
Bhedaya dance is very popular in my place

There is also Golek Menak dance

Bhedaya and Golek Menak dances are from my place

Writer: Meita Ciben Rubiyanisa (Rubiyanisa, 2019)

Based on the poetry, Meita, a fourth-grade student, has understood about the diversity of cultures that exist in Indonesia indicated by the excerpt "Indonesia has a lot of diversity. One of them is cultural diversity". Meita mentions cultural diversity, one of which is the diversity of dances found in her area, namely Bhedoyo and Golek Menak dances. The excerpt is "There are many types of culture. One of them is the local dance. Bhedoyo and Golek Menak dances are from my place". (Steiner, Nash, \& Chase, 2008) multicultural literature is an effective medium for teaching and introducing cultural diversity to students. Multicultural literature also teaches not to discriminate individuals anywhere who have racial, gender, religious, ethnic, and other differences. By using multicultural literature media, students from various cultural backgrounds can understand and see themselves and others through literature.

\section{Respect for Social Class Equality}

\section{Tempeh}

Tempeh is from Yogyakarta

and made from soybeans

I like tempeh

Tempeh is white like a cloud

In the past, people didn't eat fish

Neither they ate meat

They only eat tempeh

People were colonized by the Dutch

And they were poor and forced to work

And they had no time

For fishing and hunting

They only ate leftover soybeans

Filled with soft molds like snow

Tempeh is the same as timpuh

But not milk nor books

Tempeh is delicious

I'm the queen of tempeh

Every mother cooks tempeh

I love to steal it

\section{Writer: Abinaya Ghina Jamela (Jamela, 2018)}

The multiculturalism value contained in the poetry is the absence of social class equality, that is, the poor are colonized and forced to work. Abinaya says that in the past people did not eat fish and meat, but tempeh. Poor people have been colonized by the Dutch. Poor people were forced to work and had no time to fish and hunt for their daily needs. They only ate moldy leftover soybeans. Abinaya, a seven-year-old child, has understood the meaning of multiculturalism, namely the need for equality in the socio-economic class.

\section{Respect for Ethnic Diversity}

\section{Ethnics}

We must respect between ethnic groups

Despite different religions, we must not insult

Indonesia has 17,500 and 1,000 languages

We must unite with each other 
Indonesia must unite and respect each other

Not hostile to avoid a fight

Must unite, unite from now on

Must be united

Writer: Abi (Abi, 2019)

The content of multiculturalism in the poetry is mutual respect between ethnic groups and must not insult religious differences. Abi, a fourth-grade student, has understood to live in mutual respect. It is seen from the excerpt is "We must respect between ethnic groups. Despite different religions, we must not insult. We must unite with each other."Abi says that fellow Indonesian citizens must unite and respect each other, not be hostile and fight. The excerpt is "Indonesia must unite and respect each other not hostile to avoid a fight." Based on the verses of the poem, Abi, fifth-grade elementary school student, has understood multiculturalism. Based on the poetry stanza, Abi, the student of fifth-grade elementary school, has understood about multiculturalism. The explanation about the quote was strengthened by Arslan, who stated that multicultural education teaches the students to be able to respect each other towards diversity and be able to collaborate without seeing to the ethnic and cultural backgrounds (Arslan, 2013).

\section{Respect for Gender Equality}

\section{The Story of a Woman}

Once, women could not read, write nor study

They only washed, swept, mopped, cooked, and gardened.

They were like servants, like lionesses.

Then. born a baby girl named Johana

She was smarter than her father, smarter than all men.

Despite being a woman, she continued to study with her brother, Mathew

Johana was very smart like Einstein.

She and her mother liked to talk about gods, but her father, a priest,

didn't like it and threw Johana into her bed,

tortured her mother.

Mathew protected Johana like a male penguin protecting his family.

But, Mathew was sick, coughing like a truck.

Mathew died.

Johana was sad.

Johana received a gift book in Greek,

a famous Hommer book

Her father tried to read,

but did not understand Angrily,

her father made Johana scrape all the

letters as clean as the sky after the rain

Johana fought back

She was punished, whipped by her father.

Writer: Abinaya Ghina Jamela (Jamela, 2018)

The poetry excerpt above explains the gender gap. Abinaya, a little girl as a poet who is only 7 years old, knows about discrimination experienced by women. Women in the past did not have the freedom to get an education. They should not read, write, and study. The position of women at that time was lower than that of men. They only did the washing, sweeping, mopping, cooking, and gardening like servants. Women often got torture and punishment from men. The explanation of the excerpt was confirmed by Arslan, who stated that multicultural education views that all students have the same position and equal opportunity in obtaining education without any regardless of their social class, race, ethnicity, religion, or gender characteristics( Arslan, 2013). 


\section{Respect for Language Diversity}

\section{My Indonesia}

Various religions

Various customs

Various tribes

Diverse languages

My Indonesia ...

The beauty of the

diversity of my country

The differences unite us

Difference doesn't

make a fight

\section{Writer: Chicanti Putri Yuniarahma (Yuniarahma, 2019)}

The excerpt in the poetry shows that Indonesia already has a diversity of religions, customs, ethnicities, and languages. Chicanti mentions that diversity is a beauty that exists in her country. These differences can unite Indonesia. Based on the excerpt, Chicanti does not mention each of the diversity of languages that exist in Indonesia. Thus, the introduction of a variety of languages in Indonesia needs to be given.

\section{Respect for Religious Diversity}

\section{Religion}

Islam, Buddhism, Hinduism, Christianity, Confucianism,

and catholicism

They are all religion names

Different from each other

Believe in their faith

Different worship

Different rules

We are different

Different in every religion

But we are one

Our tolerance is united

United to be strong

United to be Indonesia

\section{Writer: Fira Setyawati (Setyawati, 2019)}

The multiculturalism value contained in the poetry is the diversity of religions found in Indonesia. The diversity of religions found in Indonesia is Islam, Buddhism, Hinduism, Christianity, Confucianism, and Catholicism. Fira says that despite its diversity of religions, Indonesia must remain united and respect each other. Every religion has its worship procedures and rules. Fira also says to tolerate each other among religious believers and live together as Indonesian citizens.

\section{Respect for Racial Diversity}

\section{Ethnic Difference}

Is it that hard to acknowledge differences?

Is it that hard to respect differences? 
Even though we have different tribes and

races, we still get along well

A falling leaf, we must respect each other

After the sprinkled sand, we must get

along well together

As fellow human beings, we must maintain unity and

the integrity of Indonesian tribes

\section{Writer: Lulu Munakumala (Munakumala, 2019)}

The values of multiculturalism in the poetry are mutual respect and mutual recognition of racial and ethnic differences. Lulu Munakumala, a fourth-grade student, has understood the meaning of multiculturalism that Indonesia is a diverse country. She invites to recognize the existence of ethnic and racial differences and to respect each other's differences. Lulu also teaches us to live in harmony despite different tribes and races. The excerpt is "Is it that hard to acknowledge differences? Is it that hard to respect differences? Even though we have different tribes and races, we still get along well." Lulu also says that fellow human beings must maintain the unity and integrity of Indonesia. The excerpt is "As fellow human beings, we must maintain the unity and integrity of Indonesian tribes."

\section{Respect for Skin Color Diversity}

\section{Black and White}

Hi, friends

Do you know black and white?

Color?

Yes, friends ... it's color

Skin color,

Our skin colors are different, friends

Sorry ... You're black

Because you're from Papua

And me?

I'm a bit whiter than you

Because I'm from Java

You and $\mathrm{Me}$

Black and white

Papua and Java

But we respect each other

We are friends

And we are brothers

We are Indonesia

\section{Writer: M. Yuma Briliant (Briliant, 2019)}

The poetry is full of multiculturalism values found in the verses. M. Yuma Briliant, a second-grade student, has understood the diversity of skin colors in Indonesia. He mentions the difference between Black and White skin colors. Black is from Papua and white from Java. He also understands to respect each other even though there are differences in skin color. It is seen in the third verse in the word "sorry" that is "Sorry ... You're black Because you're from Papua. And me? I'm a bit whiter than you because I'm from Java." M. Yuma Briliant also understands mutual respect. The excerpt is found in the fourth verse "But we respect each other. We are friends. And we are brothers. We are Indonesia.

\section{Respect for Pluralism}

\section{Love and Respect Each Other}

I and my friends respect each other 
Even though my friends are from different religions

They still respect each other

My friends help each other

They help each other when in trouble

When I worship, they respect

When they worship, I respect

I love them very much for helping me

They also love me for helping them

I am very happy

because they help me

\section{Writer: Rafi (Rafi, 2019)}

The value of multiculturalism contained in the poetry is pluralism that is mutual respect and tolerance. Through his poetry, Rafi says that he and his friends respect each other despite different religions. They help each other when in trouble. When they worship, they respect and value one another. "When I worship, they respect. When they worship, I respect." Their friendship is full of tolerance and pluralism. They love and help each other. Based on the poem, it shows that Rafi as a fourth-grade student has understood the meaning of multiculturalism, namely mutual respect and tolerance for diversity or plurality.

\section{Respect for Equality of Rights}

\section{Slave}

In America, there is a slave

Chained, beaten, punished,

Not given food.

They persistently work, and some slaves were released.

Sometimes there is a slave not released

and the governor was a European.

And the black man is a slave.

Those who are lazy to work will

be whipped.

But isn't that

allowed, to be a slave?

\section{Writer: Abinaya Ghina Jamela (Jamela, 2018)}

Based on the poetry excerpt, Abinaya conveys that there are no equal rights experienced by slaves. Abinaya explains that in America there is a slave who is chained, beaten, punished, and not given food. Slaves are oppressed and do not have the same equality of rights as the people above them. Slaves do not have freedom. They are constantly forced to work and whipped if they are lazy to work. The slaves are black people and the white people above them are Europeans. Abinaya, a seven-year-old child, has understood the meaning of multiculturalism, which is about equality of rights that all people have the same rights and must not make someone a slave.

\section{Respect for the Diversity of Customs}

\section{Papua}

It is as hot in Papua like my hand is holding the sun.

But it rains a lot

there. Papuans don't wear pants, skirts nor clothes. 
Women wear dried leaves tied up

and men wear dried

and seeded fruit, called Koteka.

If you are sick in Papua, it is difficult to find a doctor.

They go to a shaman and take herbal medicine from the forest.

Papua's forests are hideous.

Many trees, plants, animals, and they have a bird of paradise in Papua.

There are also kangaroos, but they are different.

They are small and colorful.

Houses in Papua are also small, the roof is made of leaves,

the walls are made of rattan, and their floors are the earth with no windows.

They like to dance and sing while playing drums.

Writer: Abinaya Ghina Jamela(Jamela, 2018)

The poetry above illustrates that Abinaya Ghina Jamela can imagine the conditions in Papua. Abinaya tells that in Papua it is very hot like holding the sun, it rains a lot there. Abinaya says that women in Papua use dried leaves filled as their clothes and men in Papua use seeded and dried fruits, called Koteka. Koteka is a male genital closure in Papua. Abinaya also conveys the tradition in Papua, which is when one is sick in Papua, it is difficult to find a doctor. He goes to a shaman and takes medicine made from plants obtained from the forest. The forests in Papua are scary and have lots of trees, plants, and birds of paradise. Abinaya conveys the form of houses in Papua is small. The roof is made of leaves, the walls are made of rattan, the house does not have windows and the roof is the earth. Papuans also have a tradition of dancing and singing while playing drums.

\section{Respect for Pattern of Behavior}

\section{Hero}

There's a man named Mimo

He always takes me anywhere.

His stomach is fat like a ball, very adorable.

His voice soft like my favorite T-shirt

and her arms are warm like the water

I drink when I cough.

He likes to invite me to jump like a rabbit

and frog until my mother shouts

like the sound of a frog.

He taught me to paint,

write poetry, swim, read, discuss,

and punch kids that disturb me.

When I'm sick, he takes care of me

like a prince.

I like the story

about Naya's library and monsters.

He's my cool superhero

and we will go to Paris.

Writer: Abinaya Ghina Jamela(Jamela, 2018) 
Abinaya says that she already has a very good boyfriend. His name is Mimo. Mimo has a very good behavior pattern. Mimo always accompanies Abinaya anywhere. Mimo's voice is very gentle and friendly. Mimo taught Abinaya to jump like a rabbit and a frog. Mimo also taught Abinaya to paint, write poetry, swim, read, discuss, and punch the children that disturb him. When Abinaya is sick, Mimo takes care of her. Abinaya often listens to stories from Momo. The story she likes is Naya's library and monsters. Abinaya takes Mimo as her superhero and they will go to Paris.

\section{Respect for Educational Equality}

\section{The Story of a Woman}

Once, women could not read, write nor study

They only washed, swept, mopped, cooked, and gardened.

They were like servants, like lionesses.

Then. born a baby girl named Johana

She was smarter than her father, smarter than all men.

Despite being a woman, she continued to study with her brother, Mathew

Johana was very smart like Einstein.

She and her mother liked to talk about gods, but her father, a priest,

didn't like it and threw Johana into her bed,

tortured her mother.

Mathew protected Johana like a male penguin protecting his family.

But, Mathew was sick, coughing like a truck.

Mathew died.

Johana was sad.

Johana received a gift book in Greek,

a famous Hommer book

Her father tried to read,

but did not understand Angrily,

her father made Johana scrape all the

letters as clean as the sky after the rain

Johana fought back

She was punished, whipped by her father.

Writer: Abinaya Ghina Jamela (Jamela, 2018)

Through poetry, Abinaya explains that there was no educational equality between women and men. At that time, women were not allowed to read, write, and study. Abinaya tells the story of Johana, a girl. She is smarter than her father and all men. Despite a woman, Johana always studies with her brother named Mathew. Johana was very smart like Einstein. Johana and her mother were often tortured by their father. Mathew always protected Johana. However, Mathew finally died sick. Johana received a gift book in Greek, a Hommer book. Her father tried to read but did not understand. His father told Johana to ruin the writing in the book because he could not understand it. When Johana fought back, Johana was punished and whipped by her father.

\section{Tolerance}

\section{Multicultural}

Even though we have different tribes and customs

But we still respect other tribes

With different cultures and religions

As the people of Indonesia

We must not be enemies 
Despite different religions

We tolerate each other

Different religions such as Islam,

Christianity, Confucianism, Catholicism,

Buddhism, and Hinduism

We still live in harmony and peace

There is no hostility

\section{Writer: Icha Amelia (Amelia, 2019)}

The content of multiculturalism in poetry is tolerance and mutual respect. Icha, through her poetry, conveys mutual respect despite different tribes, customs, cultures, and religions. Icha also says that as Indonesian people, they should not be enemies. The religions in Indonesia are Islam, Christianity, Confucianism, Catholicism, Buddhism, and Hinduism. Despite different religions, fellow Indonesian people must tolerate one another, live in harmony and peace, and avoid hostility. The statement is supported by Miftah who states that by understanding the values of multiculturalism and applying them based on ideology, it is expected to make the community less fanatical in addressing differences, reducing intercultural conflicts, embodying tolerance, and showing mutual respect in understanding differences (Miftah, 2016).

\section{CONCLUSION}

Literature containing multiculturalism can be used to introduce and teach students to show respect for differences in culture, ethnicity, religion, social class, educational equality, skin color, gender equality, tolerance, and pluralism. Based on the results of the analysis of the multiculturalism content in the poetry "Keragaman Budaya Indonesia" and "Sehimpun Puisi. Resep Membuat Jagat Raya" by elementary school students, The poetry was written by the students has contained fourteen values of multiculturalism including mutual respect for the equality of culture, social class, ethnicity, gender, language, religion, race, skin color, pluralism, rights, customs, behavior patterns, education, and tolerance. Based on this, it shows that elementary school students have understood the values of multiculturalism that can be shown in the poetry written. The internalization of multiculturalism values must be given to students from an early age so that they can grow into individuals who can respect each other, respect and tolerate differences and live in harmony. The teacher should teach the students to be free from the prejudices of discriminations of religions, gender, social class, skin color, and so on. The multiculturalism values can be instilled through children's multiculturalism literature, one of which is through children's poetry containing multiculturalism.

The results of this study can be used to determine the multicultural content contained in children's poetry. Besides, the results of this study can also be used to instill the values of multiculturalism in children and can be used to teach writing poetry containing multiculturalism in elementary school children

The authors believe that it is important to instill the value of multiculturalism early in elementary school children. Multiculturalism is introduced to teach students to respect and live harmoniously and be free from prejudice to discrimination of religion, gender, race, culture, skin color, social class, educational equality, and diversity. The cultivation of the value of multiculturalism can be done through children's literature through poetry and children's prose. Therefore, there is a need for further research on children's literary multiculturalism.

\section{LIMITATION AND STUDY FORWARD}

The limitation of this research is that it only discusses explanations from the perspective of multiculturalism in children's poetry by elementary school students in a collection of poems entitled "Keragaman Budaya Indonesia " and "Sehimpun Puisi. Resep Membuat Jagat Raya ". The findings of this research are expected to be used as a reference for conducting further research on children's poetry containing multiculturalism to add to the scientific treasures in the field of Indonesian Language and Children's Literature.

\section{ACKNOWLEDGMENT}

The researcher would like to thank LPDP BUDIDN as the research sponsor. Thanks to the rector of Sarjanawiyata Tamansiswa University, Yogyakarta, who has permitted for the research to continue his doctoral study. Also, thanks to the promoter, co-promoter 1, and co-promoter 2 who have guided in conducting this study.

\section{AUTHORS CONTRIBUTION}

\section{Anang Sudigdo}

He is a doctoral student of the Indonesian Language program at Sebelas Maret University in Surakarta, Indonesia, and a lecturer at Sarjanawiyata Tamansiswa University Yogyakarta, Indonesia. In this research, his role was collecting the data on multiculturalism poetry written by elementary school students and analyzing the multiculturalism values therein. 


\section{St. Y. Slamet}

He is a professor at Sebelas Maret University in Surakarta, Indonesia as well as the promoter. His role was guiding in collecting the data on multiculturalism poetry.

\section{Retno Winarni}

He is a professor at the Sebelas Maret University in Surakarta, Indonesia as well as the promoter. Her role was guiding in analyzing the poetry containing multiculturalism.

\section{Nugraheni Eko Wardani}

$\mathrm{He}$ is a doctor at Sebelas Maret University in Surakarta, Indonesia as well as the co-promoter. Her role was guiding in the preparation of the article.

\section{REFERENCES}

1. Abdullah, A. C. (2009). Multicultural Education in Early Childhood: Issues and Challenges. Journal of International Cooperation in Education, 12(1), 159-175.

2. Abi. (2019). Keragaman Budaya Indonesia (Sudigdo, A). Blora: Pataba Press.

3. Amelia, I. (2019). Keragaman Budaya Indonesia (Sudigdo, A). Blora: Pataba Press.

4. Arslan, H. (2013). Multicultural Education. Approaches, Dimension, and Principles. (R. G. Arslan, Hasan, Ed.). Newcastle Upon Tyre: Cambridge Scholars Publishing. Retrieved from https://www.researchgate.net/publication/284446148

5. Brilliant, M. Y. (2019). Keragaman Budaya Indonesia (Sudigdo, A). Blora: Pataba Press.

6. Hasanuddin. (2015). Sastra Anak, Kajian Tema, Amanat dan Teknik Penyampaian Cerita Anak Terbitan Surat Kabar. Bandung: Angkasa.

7. Heru, K. (2013). Sastra Anak (dalam Kajian Strukturalisme, Sosiologi, Semiotika, hingga Penulisan Kreatif. Yogyakarta: Graha Ilmu.

8. Jamela, A. G. (2018a). Sehimpun Puisi Resep Membuat Jagat Raya. Padang: Kabarita.

9. Jamela, A. G. (2018b). Sehimpun Puisi Resep Membut Jagat Raya. Padang: Kabarita.

10. Kamil, M. (2018). Cultural Tolerance, Diversity, and Pluralism: The Recognition of Yogyakarta as The City of Tolerance. Journal of Local Government Issues, 1(1), 23. https://doi.org/10.22219/LOGOS.Vol1.No1.23-36

11. Kijima, M. (2005). Schooling, multiculturalism, and cultural identity: A case study of Japanese senior school students in a secondary school in South Australia. International Education Journal, 5(5), 129-136.

12. Klaus, K. (2004). Content Analysis an Introduction to its Methodology. California: Sage Publication, Inc.

13. Mahfud, C. (2011). Pendidikan Multikultural. Yogyakarta: Pustaka Pelajar.

14. Maliki, Z. (2010). Sosiologi Pendidikan. Yogyakarta: Gadjah Mada University Press.

15. McIver, P. (2018). A Content Analysis of Multicultural Children's Books in the Republic of Korea and America. Journal of Literature and Art Studies, 8(1), 67-80. https://doi.org/10.17265/2159-5836/2018.01.008

16. Miftah, M. (2016). Multicultural Education in the Diversity of National Cultures. QIJIS (Qudus International Journal of Islamic Studies), 4(2), 167. https://doi.org/10.21043/qijis.v4i2.1766

17. Miles, B. M. \& M. H. (2009). Analisis Data Kualitatif. Jakarta: UI-Press.

18. Mingshui, C. (2002). Multicultural Literature for Children and Young Adults. London: Greenwood Press.

19. Monanti, N. F., Bassil, J., Lilian, M., Author, C., \& Fredrick, N. (2014). Children's Poetry and Personality Formation : Analysis of Gusii Children 's Song Texts, 5(2), 140-148.

20. Munakumala, L. (2019). Keragaman Budaya Indonesia (Sudigdo, A). Blora: Pataba Press.

21. Naim, Ngainun \& Sauqi, A. (2011). Pendidikan Multikultural: Konsep dan Aplikasi. Yogyakarta: Ar-Ruzz Media.

22. Nurgiyantoro, B. (2013). Sastra Anak pengantar Pemahaman Dunia Anak. Yogyakarta: Gadjah Mada University Press.

23. Rachmawati, Pai, Yi-Fong \& Chen, Y. (2014). “ THE NECESSITY OF MULTICULTURAL EDUCATION IN INDONESIA “, 2(10), 317-328. Retrieved from https://www.ijern.com/journal/2014/October-2014/25.pdf

24. Rafi. (2019). Keragaman Budaya Indonesia (Sudigdo, A). Blora: Pataba Press.

25. Ratna, N. K. (2005). Sastra dan Culture Studies: Representasi Fiksi dan Fakta. Yogyakarta: Pustaka Pelajar.

26. Rubiyanisa, M. C. (2019). Keragaman Budaya Indonesia. (Anang Sudigdo, Ed.). Blora: Pataba Press.

27. Santrock, J. W. (2015). Psikologi Pendidikan. Educational Psychologi. Jakarta: Salemba Humanika.

28. Sarumpaet, R. K. T. (2010). Pedoman Penelitian Sastra Anak. Jakarta: Yayasan Obor.

29. Setyawati, F. (2019). Keragaman Budaya Indonesia (Sudigdo, A). Blora: Pataba Press.

30. Steiner, S. F., Nash, C. P., \& Chase, M. (2008a). Multicultural Literature That Brings People Together, 62(1), 88-92. https://doi.org/10.1598/RT.62.1.12

31. Steiner, S. F., Nash, C. P., \& Chase, M. (2008b). Multicultural Literature That Brings People Together, 62(1), 2714. https://doi.org/10.1598/RT.62.1.12

32. Sudigdo, A, Slamet, S., Winarni, R., \& Ekowardani, N. (2019). The Multiculturalism of Children 's Literature : A Study about Children', s Poems in Surakarta and Yogyakarta. https://doi.org/10.4108/eai.21-12- 
Humanities \& Social Sciences Reviews

elSSN: 2395-6518, Vol 8, No 3, 2020, pp 246-259

https://doi.org/10.18510/hssr.2020.8326

2018.2282568

33. Taufiq, A. (2017). Sastra Multikultural, Konstruksi dan Praktik Diskursif Negara dalam Perkembangan Sastra Indonesia. Malang: Beranda.

34. Yuniarahma, C. P. (2019). Keragaman Budaya Indonesia (Sudigdo, A). Blora: Pataba Press.

35. Zakiyuddin, B. (2015). Pendidikan Agama Berwawasan Multikultural. Jakarta: Erlangga. 